\title{
生姜・乾姜の修治法に関する史的考察
}

\author{
堂井 美里 ${ }^{\mathrm{ab}}$ 御影 雅幸a \\ a 金沢大学大学院医薬保健学総合研究科資源生薬学研究室, 石川, $=920-1192$ 金沢市角間町 \\ b 株式会社ウチ多和漢薬，東京， $=116-8571$ 荒川区東日暮里4-4-10
}

\section{Herbological Study on the Processing of Ginger}

\author{
Misato DOUI $^{\mathrm{ab}}$ Masayuki MIKAGE ${ }^{\mathrm{a}}$ \\ a Herbal Medicine and Natural Resources, Division of Pharmaceutical Sciences, Graduate School of Medical Science and \\ Technology, Kanazawa University, Kakuma-machi, Kanazawa, Ishikawa 920-1192, Japan \\ b Uchida Wakanyaku Co., Ltd., 4-4-10 Higashi-nippori, Arakawa, Tokyo 116-8571, Japan
}

\begin{abstract}
Processing methods for the crude drugs shokyo (fresh ginger) and kankyo (dried ginger) have been different in China and Japan, although the reasons for this have not been clear. In this study, we revealed a historical transition in the processing methods for shokyo and kankyo.

We found that the name shokyo had been used for fresh ginger rhizome in China since the end of the Houhan dynasty. The name had also been used for shokyo in Japan, whereas the term shokyo was then applied to dried ginger in the Japanese pharmacopoeia during the Meiji era. With kankyo, on the other hand, several different processing methods existed in China. For example, ginger fermented in a ceramic pot after being soaked in running water and dried was called kankyo, and was strongly associated with the property 'hot'. However, we supposed that simply dried ginger, which has the property 'warm', came to be called as kankyo exclusively from the middle of the Qing dynasty. Meanwhile, only ginger dried with lime after being steamed was called kankyo in Japan. We also found that ginger whitened with lime was produced and sold in pharmacies because of a description by Shizhen $\mathrm{Li}$, to the effect that "white ginger has higher quality". This controversial method has been changed to one without the use of lime since the Meiji era.
\end{abstract}

Key words : ginger (shokyo), kankyo, preparation, historical transition

\section{要旨}

漢方生薬「生姜」および「乾姜」の修治（加工）法は中国と日本で異なっているが，その理由は明確ではない。 本研究では, 両生薬の修治法の歴史的変遷を調査した結果, 中国では後漢末期からショウガの新鮮根茎を生姜とし てきたことが明らかになった。一方，日本でも新鮮根茎を生姜としてきたが，明治時代に日本薬局方に収載する際 に，乾燥根茎を充てたことが明らかになった。また，中国では，地域により乾姜の調製法が異なっており，古い時 代には「流水に浸した後, 一度乾燥させ, 陶磁器内で醇したもの」を熱性が強し乾姜としていたが, 清代中期には 温性の乾燥根茎のみを使用するようになったと考察した。さらに, 日本では「蒸した後, 石灰を用いて乾燥させた もの」を独自に乾姜としていたが，李時珍が白色のものが良品と記したことから，石灰をま乃゙して白くしたものを 薬舗で売り出し, その是非から明治時代以降, 石灰を使用しない方法に代わったと判断した。

キーワード : 生姜, 乾姜, 修治, 歴史的变遷

\section{緒言}

ショウガの根茥に由来する生薬は『第16改正日本 薬局方』 ${ }^{1)}$ に修治の違いにより「生姜」「乾姜」の 2 種が収載されており，日本で修治品が利用される数 少ない生薬である。しかし，日本と中国で両者の原 材料であるショウガ根茎の加工方法や名称が異なっ ている。日本では, 単に乾燥させた根茎を「生姜」, 湯通しまたは蒸して乾燥させたものを「乾姜」とし
ているが, 中国では新鮮根茎を「生姜」, 乾燥根茎 を「乾姜（簡体字では干姜）」としとている（表 1 )。 すなわち，日本の「生姜」は中国での「乾姜」と同 様の調製法により得られたものであるが，両国で生 薬名が異なる理由は不明である。また，一般に生姜 は発表作用が強く，乾姜は温中作用が強いとされて いるが，如何に調製したものがそうした効果を示す のか明確ではなく，両生薬の薬効や来歴には不明な 
表 1 日本と中国に扮ける生姜・乾姜の相違

\begin{tabular}{|c|c|c|}
\hline & 日本 ${ }^{1)}$ & 中国 ${ }^{2)}$ \\
\hline 生姜 & 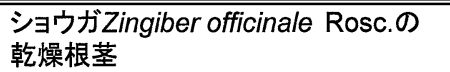 & $\begin{array}{l}\begin{array}{l}\text { ショウガZingiber officinale Rosc.の } \\
\text { 新鮮根茎 }\end{array} \\
\end{array}$ \\
\hline 乾姜 & $\begin{array}{l}\text { ショウガZingiber officinale Rosc.の根 } \\
\text { 茎を湯通し又は蒸して乾燥させたもの }\end{array}$ & $\begin{array}{l}\text { ショウガZingiber officinale Rosc.の } \\
\text { 乾燥根茎 }\end{array}$ \\
\hline
\end{tabular}

表 2 中国の本草書中の生姜・乾姜・炮姜・黒姜に関する記載内容

\begin{tabular}{|c|c|c|c|c|c|c|c|c|c|c|c|c|}
\hline \multirow{2}{*}{\multicolumn{2}{|c|}{$\begin{array}{l}\text { 年代 } \\
\text { 漢 }\end{array}$}} & \multirow{3}{*}{$\begin{array}{l}\text { 文献名 } \\
\text { 神農本草経 } \\
\text { 名医別録 }\end{array}$} & \multicolumn{2}{|l|}{$\begin{array}{l}\text { 生姜 } \\
\text { 性味 }\end{array}$} & \multirow[t]{2}{*}{ 修治法 } & \multirow{3}{*}{$\begin{array}{l}\text { 乾姜 } \\
\text { 性味 } \\
\text { 辛 }\end{array}$} & & \multirow[t]{3}{*}{ 修治法 } & \multicolumn{2}{|l|}{$\begin{array}{l}\text { 炮姜 } \\
\text { 性味 }\end{array}$} & \multicolumn{2}{|l|}{$\begin{array}{l}\text { 黒姜 } \\
\text { 性味 }\end{array}$} \\
\hline & & & & & & & 温 & & & & & \\
\hline & & & 辛 & 微温 & & & 大熱 & & & & & \\
\hline 斉 & 500 前 & 神農本草経集注 $^{57)}$ & 辛 & 微温 & & 辛 & 温·大熱 & $\begin{array}{l}\text { 凡作乾姜法 水淹三日米 去皮置流水中六 } \\
\text { 日 更去皮 然後晒干 置瓮缸中 謂之醅也 }\end{array}$ & & & & \\
\hline 宋 & 1062 & 図経本草 ${ }^{4)}$ & & & $\begin{array}{l}\text { 生姜是常 } \\
\text { 食物 }\end{array}$ & & & 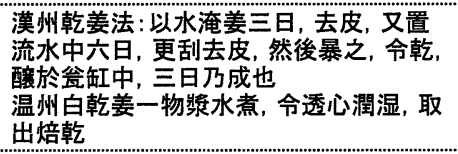 & & & & \\
\hline 蒙古 & 1248 & 湯液本草6) & 辛 & 温 & & $\begin{array}{l}\text { 大辛 } \\
\text { 辛 }\end{array}$ & $\begin{array}{l}\text { 熱 } \\
\text { 大熱 } \\
\text { 温 }\end{array}$ & 水洗, 慢火炮 & & & & \\
\hline 元 & 1295 & 本草歌括 ${ }^{11}$ & 辛 & 微温 & & 辛 & 温·大熱 & 八九月採根於長流水洗過當日晒乾 & & & & \\
\hline 明 & 1520 & 本草約言 ${ }^{5)}$ & 辛 & 温 & & 辛 & 大熱 & & 苦 & 大温 & 苦 & 温 \\
\hline & 1565 & 本草蒙筌7) & 辛 & 微温 & $\begin{array}{l}\text { 秋月採 } \\
\text { 根。沙蔵 } \\
\text { 常得新鮮 }\end{array}$ & 辛 & 温·大熱 & $\begin{array}{l}\text { 去皮日曝, 又名乾姜。 } \\
\text { 漢州造乾姜法, 以水淹姜三日, 去皮, 又 } \\
\text { 置流水中六日, 更刮去皮, 方曝乾, 醸於 } \\
\text { 㸗中三日乃成 }\end{array}$ & 苦 & & & \\
\hline & 1578 & 本草発明 ${ }^{5 I)}$ & 辛 & 温 & & 辛 & 温·大熱 & 漢州乾姜温州乾姜色白亦好 & & & & \\
\hline & 1595 & 新鉃薬性會元 ${ }^{5 \hbar)}$ & 辛 & 温 & & 辛 & 温·大熱 & 取生薑汁淹三日去皮制片晒乾置磁瓶中 & 苦 & & & \\
\hline & 1596 & 本草綱目 $^{8)}$ & 辛 & 微温 & & 辛 & 温 & 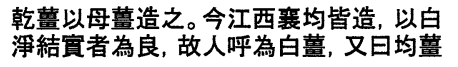 & & & & \\
\hline & 1612 & 本草原始 ${ }^{5 力)}$ & 辛 & 微温 & & 辛 & 温 & 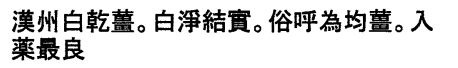 & & & & \\
\hline & 1647 & 本草乗雅半偈 ${ }^{5 \neq)}$ & & & & 辛 & 温 & 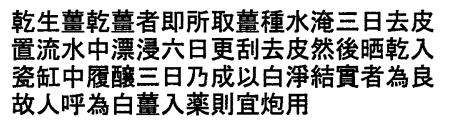 & & & & \\
\hline 清 & 清初 & 本草崇原 ${ }^{5 \eta)}$ & & & & 辛 & 温 & $\begin{array}{l}\text { 乾䔰用母增晒乾以肉厚白淨結實明亮如 } \\
\text { 天麻者為良故又名白薑 }\end{array}$ & & & & \\
\hline & 1664 & 本草述 $^{5 \text { 个) }}$ & 辛 & 微温 & & 辛 & 温 & 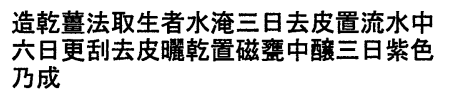 & & & & \\
\hline & 1666 & 本草匯 $^{5])}$ & 辛 & 温 & & 苦辛 & 大熱 & $\begin{array}{l}\text { 江西所造水浸三日去皮浸六日。更刮去 } \\
\text { 皮。晒乾置瓷缸中。醇三日。始成岨皮作 } \\
\text { 散 }\end{array}$ & & & & \\
\hline & 1681 & 本草詳節 ${ }^{5+1}$ & 辛 & 微温 & & 辛 & 温 & 以白淨結實母薑晒乾為之 & & & & \\
\hline & 1696 & 山居本草 ${ }^{5 i \prime}$ & 辛 & 温 & & 苦辛 & 大熱 & 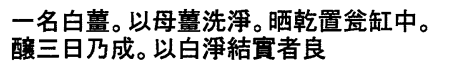 & & & & \\
\hline & 1753 & 長沙薬解 5 ) & 辛 & 温 & & 辛 & 温 & & & & & \\
\hline & 1757 & 本草従新 $^{5 \mathrm{t})}$ & 辛 & 温 & & 辛 & 熱 & 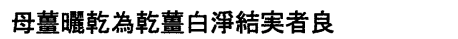 & & & 辛苦 & 大熱 \\
\hline & 1758 & 医林纂要探源 ${ }^{\text {》 }}$ & 辛 & 温 & & 辛 & 熱 & & 辛苦 & 大熱 & 辛苦 & 温 \\
\hline & 1769 & 本草求真 ${ }^{5 夕)}$ & 辛 & & & 辛 & & 母姜晒乾為乾姜 & 苦 & 大熱 & & \\
\hline & 1773 & 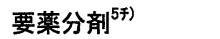 & 辛 & 微温 & & 辛 & 大熱 & & & & & \\
\hline & 1789 & 羅氏會約医鏡 ${ }^{\text {(M) }}$ & 辛 & 熱 & & 辛 & 温 & & 辛苦 & 大熱 & & \\
\hline & 1790 & 本草輯要 ${ }^{57 \text { ) }}$ & 辛 & 温 & & 辛 & 温 & 母薑晒乾者為乾薑 & 辛苦 & 大熱 & & \\
\hline & 1812 & 薬籠小品 ${ }^{5 卜)}$ & 辛 & 温 & & 辛 & 熱 & & 辛苦 & 大熱 & & \\
\hline & 1815 & 本草算要 ${ }^{5+)}$ & 辛 & 温 & & 辛 & 熱 & & 甘 & 温 & & \\
\hline & 1827 & 類経證治 ${ }^{5=)}$ & 辛 & 温 & & 苦辛 & 大温 & 取母姜晒干為干姜焼黒為黒姜 & & & & \\
\hline & 1828 & 本草正義5双 & 辛 & 熱 & & 辛 & 熱 & & & & & \\
\hline & 1829 & 本草述録 $^{5 \text { k) }}$ & 辛 & 微温 & & 辛 & 温 & & 苦 & 大熱 & & \\
\hline & 1837 & 本草 ${ }^{\prime \prime}$ & 辛 & 温 & & $\begin{array}{l}\text { 辛微 } \\
\text { 苦 }\end{array}$ & 温熱 & & & & & \\
\hline & 1862 & 本草害利 ${ }^{5 n)}$ & 辛 & 温 & & 大辛 & & 晒乾, 姜白結実者良 & & & & \\
\hline & 1885 & 本草綱目易知録5七) & 辛 & 温 & & 辛 & 温 & & & & & \\
\hline & 1887 & 本草簡明圖説 57$)$ & 辛 & 温 & & 辛 & 温 & & & & & \\
\hline & 1897 & 本草撮要類編 ${ }^{\text {^) }}$ & 辛 & 温 & & 辛 & 熱 & 老葍晒乾為乾瞢 & & & 辛苦 & 大熱 \\
\hline & 1904 & 本草思辨録 ${ }^{55)}$ & & & & & & 乾薑以母蔷去皮依法造之 & & & & \\
\hline
\end{tabular}


表 3 日本の本草書中の生姜および乾生姜に関する記載内容

\begin{tabular}{|c|c|c|}
\hline 文献名 & 生姜 & 乾生姜 \\
\hline 1623 和名焦并異名製剂記 ${ }^{57)}$ & & 生ナルハシカミヨ其ノママ日ニホシタルラ云フ \\
\hline 1631 新添修治箘要 ${ }^{5 *}$ & & 乾生姜トハナマ生姜ヨホシタル也 \\
\hline 1669 新編霊宝薬性能毒 $\left.{ }^{54}\right)$ & & $\begin{array}{l}\text { 乾生堎卜ハ唯干[タダホシ]タル姜[ハジカミ] } \\
\text { 也干姜二代用ス }\end{array}$ \\
\hline 1687 食用簡便 ${ }^{5 x)}$ & & $\begin{array}{l}\text { 干姜[ホシシヤウガ] 切片テ日ニ乾シ用ユ主 } \\
\text { 治禁好生姜ト同シ }\end{array}$ \\
\hline 1698 広益本草大成 ${ }^{5 \tau)}$ & & $\begin{array}{l}\text { 生姜ヲ切片[キリヘギ]テ陰乾[カゲホシ]スル } \\
\text { 者也 } \\
\text { 薜巳ガ方書二謂所ノ乾姜八多八眞乾姜二非 } \\
\text { ズ。乾生姜习以テ云 }\end{array}$ \\
\hline 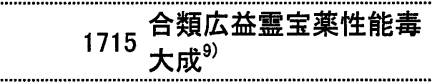 & & $\begin{array}{l}\text { 乾生姜トハ只[タダ]千[ホシ]タル姜[ハジカミ] } \\
\text { ナリ干姜ニ代[カへテ用ュ }\end{array}$ \\
\hline 1723 六八本草 ${ }^{5 \dagger)}$ & 生姜ハ常二用ル生[ナマ]ノ生姜ナリ & $\begin{array}{l}\text { 干生姜ハ生姜ヨ秋冬ノ内ニ其ママカハカシタ } \\
\text { ルモノリ }\end{array}$ \\
\hline 1723 本草㹕譜 $\left.{ }^{51}\right)$ & & 乾生姜ハ母姜习以テ皮去日乾用 \\
\hline 1726-1776 用薬須知 ${ }^{10)}$ & & $\begin{array}{l}\text { 乾生美八生姜ヨキザミソノママ日乾シテ收メ用 } \\
\text { ルナリ俗医多ク此ラ以乾姜ト為ルハ誤ナリ }\end{array}$ \\
\hline 1729-1810 本草綱目訳説53) & & $\begin{array}{l}\text { 法ノ如製ス只乾スモハハ生干ニテ乾生姜ト云 } \\
\text { 流水二不浸只切テ乾生姜卜云日本ニテハ生干 } \\
\text { シト云 }\end{array}$ \\
\hline 1818-1829 本草古義57) & & $\begin{array}{l}\text { 秋冬之際採老根以少洗過去皮切尾日乾即今 } \\
\text { 云乾生蕈 }\end{array}$ \\
\hline 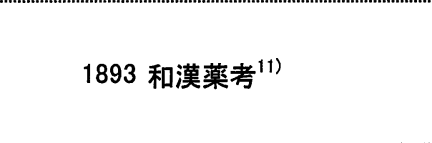 & 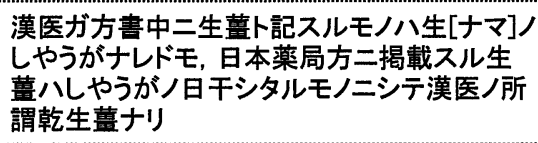 & 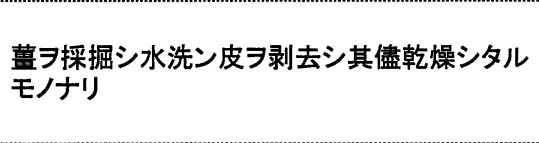 \\
\hline 1918 和漢薬物学 ${ }^{12)}$ & $\begin{array}{l}\text { 本品は多年生草本たる生薑[シヤウガ](Zin. } \\
\text { officinale, Roscoe.)の根 (根茎)なり }\end{array}$ & \\
\hline
\end{tabular}

点が多い。なお, 単に乾燥させたショウガ根茥を「乾 生姜」と呼ぶことがあり，本稿ではこの用語を使用 した。

本研究では, 中国および日本の本草書，医方書の 記載内容から, 生姜ならびに乾姜の歴代の調製法を 調査し，両生薬の来歴を明らかにすると同時に，中 国と日本で生薬名が異なる理由を考証した。

\section{1 生姜の調製法の歴史的変遷}

\section{（1）中国}

後漢代に書かれた医方書である『傷寒論』尚中の桂 枝湯などの生姜配合処方には，生姜に「切」の加工 を施すように規定されている。「切」は刃物で切る ことを意味していると考えられ，新鮮品は刃物で切 れることから, 生姜として乾燥品ではなく新鮮品を 用いたと推察できる。なお，同書では「切」を施す のは生姜のみであり, 生姜は他の生薬とは異なり新 鮮品を使用していたことが裏付けられる。時代が下 り，『図経本草』(1062）に，「生姜是常食物」，『本 草蒙筌』7) (1565) に「常得新鮮」とあり, 後漢以降, 新鮮根茥を生姜として用いたことがわかる（表 2）。

(2) 日本
『六八本草』 ${ }^{5 \dagger)}(1723)$ に「生姜八…生ノ生姜ナ リ」とあり，日本でも新鮮根茎を生姜として用いて いたことがわかる。一方，『和漢薬考』11) (1893) に 「漢医ガ方書中二生亩卜記スルモノハ生ノしやうが ナレドモ, 日本薬局方二揭載スル生亩ハしやうがノ 日干シタルモノニシテ漢医ノ所謂乾生薑ナリ」とあ る（表３）。また，『改正日本薬局方』13)（1891）に は畺根の名で生姜が収載されており，「本品八通常 長片二截り乾燥ス」とある。すなわち，明治時代に 生姜を日本薬局方に収載する時には，乾生姜を採用 したが，漢方医は新鮮根茥を用いていたことがわか る。

\section{2 乾姜の調製法の歴史的変遷}

\section{（1）中国（表 2 ）}

乾姜の名は馬王堆出土の前漢代の医書である『五

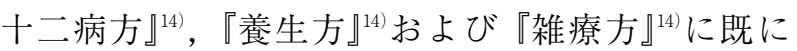
見られ，加えて『五十二病方』敫には「枯姜（原文 は畺)」の名もあり，ショウガ根茎を加工して用い ていたことが窥われる。一方，これらの文献には生 姜の名は見られず，「姜（畺，畺などの文字を使 用)」と記されている。これらのことから，「姜」は 
表 4 日本の本草書中の乾姜に関する記載内容

\begin{tabular}{|c|c|c|c|c|c|}
\hline 年代 & 文献名 & 流水に浸して調製 & 流水に浸した後，醸して調製 & 煮製( ${ }^{*}$ は蒸製) & 石灰を用いたもの \\
\hline 1562 & 本草異名記 ${ }^{5 J)}$ & $\begin{array}{l}\text { 九月十月ニ生姜习トッテ井花水 } \\
\text { 二漫スコト三日シテ皮ヨケヅリ } \\
\text { 去テ流水ニ六日漫ス。毎日 } \\
\text { 水ヨカエテサテ日ニ乾シ焙リ用 } \\
\text { ユ }\end{array}$ & & & \\
\hline 1623 & $\begin{array}{l}\text { 和名集并異名 } \\
\text { 製剂記 }^{57)}\end{array}$ & $\begin{array}{l}\text { 生薑习九月十月二採テ井花水 } \\
\text { 三浸シ上皮习削リ去テマ } \\
\text { 二六日ヒタシ毎日水ヨカエル也 } \\
\text { サテ日ニホシ }\end{array}$ & & & $\begin{array}{l}\text { 薬屋ニ売ハ蒸シ石灰ニマフ } \\
\text { シ置クナリ }\end{array}$ \\
\hline 1631 & $\begin{array}{l}\text { 新添修治籍要 } \\
\text { : }\end{array}$ & $\begin{array}{l}\text { 生姜习寒ノ中ノ水二浸事一七日 } \\
\text { ジ皮ヨ去リ日ニ乾シ剉ミ焙フ } \\
\text { ル }\end{array}$ & & & \\
\hline $\begin{array}{r}1579- \\
1657\end{array}$ & 宣子製剂記 ${ }^{5 /)}$ & $\begin{array}{l}\text { 入門私日取生者能皮习ケツリ } \\
\text { 去寒ノ中流水ニ浸コトヒ日ニシ } \\
\text { テ取上ケ日乾セハ色白シキサミ } \\
\text { 焙ル }\end{array}$ & $\begin{array}{l}\text { 本草可見取生者水二潼スコト三日去皮置流 } \\
\text { 水中六日更去皮晒干䤃磁会中三日ニシテ紫 } \\
\text { 色ニシテ乃成 }\end{array}$ & & 石灰ヨスリ白クスルハ非ナリ \\
\hline 1669 & 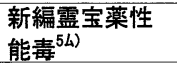 & $\begin{array}{l}\text { 生姜习寒ノ中三七日水二浸シ } \\
\text { 皮ヨ去リ日ニ晒テ惭ミ焙ル }\end{array}$ & & & \\
\hline 1680 & 図解本草 ${ }^{16)}$ & & 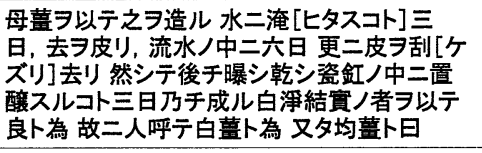 & & $\begin{array}{l}\text { 今二廣嶋ヨリ出ハ者ノ石灰ノ } \\
\text { 気多シ }\end{array}$ \\
\hline 1689 & 炮灻全書 ${ }^{5 \downarrow)}$ & & 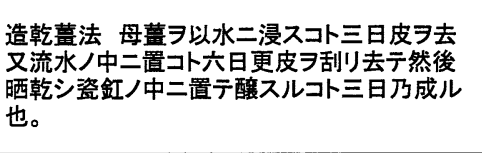 & 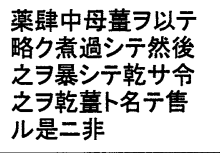 & \\
\hline 1698 & 広益本草大成 ${ }^{5}$ & & $\begin{array}{l}\text { 母姜ノ腐不者习擇水漫コト三日シテ薄皮习去。 } \\
\text { 又冷水二浸スコト六或ハ日モ亦可也。 } \\
\text { 取出テ又外皮一片习刮去テ日晒シ乾磁器二 } \\
\text { 蔵置コト三日メ用ユ }\end{array}$ & $\begin{array}{l}\text { 今薬店ニ母姜省 } \\
\text { 過テ晒シ乾シ此 } \\
\text { 號テ乾姜トス。甚ダ } \\
\text { 非也 }\end{array}$ & \\
\hline 1723 & 六八本草 ${ }^{5 \dagger)}$ & & 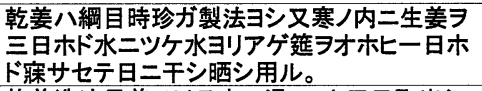 & & $\begin{array}{l}\text { 今薬肆二売ル所ノ乾姜ハ生 } \\
\text { 姜习蒸シテ石灰ヨマズシタル } \\
\text { モノナリ用ユ可不。 }\end{array}$ \\
\hline 1723 & 本草製譜 ${ }^{51)}$ & & 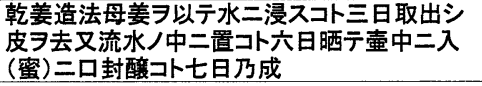 & $\begin{array}{l}\text { 按荣者之有者母姜 } \\
\text { ᄏ以劣過 }\end{array}$ & $\begin{array}{l}\text { 或蒸石灰二找セ眖テ乾姜卜 } \\
\text { 名ケ偽売用可不 }\end{array}$ \\
\hline $\begin{array}{r}1726- \\
1776\end{array}$ & 用薬須知 ${ }^{10)}$ & & 長流水ニヒタシ製ス & & $\begin{array}{l}\text { 薬家多ク乾生姜其色ノ之白 } \\
\text { カラキヨ欲シテ石灰ヨ以テ緾 } \\
\text { [マプ]シ収メテ之ヨ売ル毒有 } \\
\text { リ }\end{array}$ \\
\hline 1729 & 一本堂薬選 ${ }^{17)}$ & & & & 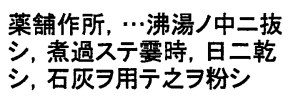 \\
\hline 1734 & 薬籠本草 ${ }^{18)}$ & & $\begin{array}{l}\text { 弘景ノ日乾薑ヨ作ノ法水淹コト三日皮ヨ去流 } \\
\text { 水ノ中二㯰コト六日晒乾瓷釭中二置醸スルコ } \\
\text { ト三日乃成 }\end{array}$ & & $\begin{array}{l}\text { 本邦売薬家ノ製法…皮习去 } \\
\text { 不之ヨ烝 而後石灰二拌晒 } \\
\text { 乾其味辛裂不 }\end{array}$ \\
\hline 1756 & 本草焦 ${ }^{5 n)}$ & & $\begin{array}{l}\text { 母姜ᄏ以水二浸コト三日皮去又流水ノ中置六 } \\
\text { 日更皮刮去り然後晒シ乾瓷釭ノ中二置醉コト } \\
\text { 三日乃成也 }\end{array}$ & 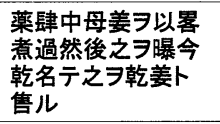 & $\begin{array}{l}\text { 或八其ノ色白欲石灰以纆 } \\
\text { 収者有。毒有俱二是非 }\end{array}$ \\
\hline 1778 & 千金方薬註 ${ }^{57)}$ & & $\begin{array}{l}\text { 綱目ニ流水二浸シ器ニ入レ蓋ヒ宿Э経テ紫色 } \\
\text { 二変ズ是レー法ナリ }\end{array}$ & & $\begin{array}{l}\text { 参河乾姜ハ石灰Э以テ製ス } \\
\text { 毒アリ }\end{array}$ \\
\hline $\begin{array}{r}1729- \\
1810 \\
\end{array}$ & $\begin{array}{l}\text { 本草網目訳説 } \\
\text { 引) }\end{array}$ & $\begin{array}{l}\text { 乾姜製法ハ生姜宿根习采り流 } \\
\text { 水ノ中ニ七日許り浸シテ製ス }\end{array}$ & & & $\begin{array}{l}\text { 薬舗二此习偽リ生干二石灰 } \\
\text { シマブシ白メ售ル用二堪不 }\end{array}$ \\
\hline 1803 & $\begin{array}{l}\text { 本草綱目啓蒙 } \\
\text { 19) }\end{array}$ & & $\begin{array}{l}\text { 乾薑八長流二数日浸シ醉シ姐スコト集解二詳 } \\
\text { ナリ自製ヨ良トス }\end{array}$ & & $\begin{array}{l}\text { 其色ノ白カランコトラ欲シ石 } \\
\text { 灰ヨ収雜ユル者アリ宜シ洗 } \\
\text { ヒ去テ用ユベシ }\end{array}$ \\
\hline $\begin{array}{r}1818- \\
1829\end{array}$ & 本草古義 ${ }^{57)}$ & & & & 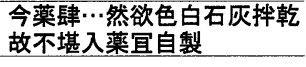 \\
\hline 1841 & 古方薬品考 ${ }^{20)}$ & & 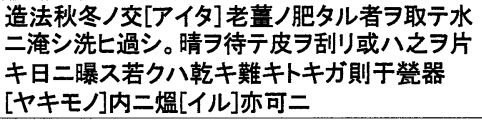 & & \\
\hline 1893 & 和漢薬考 ${ }^{(1)}$ & $\begin{array}{l}\text { 生䔰习寒中三七日間水中ニ浸 } \\
\text { 漬シ皮习除去シ日干シ }\end{array}$ & & $\begin{array}{l}\text { 地下茎习蒸シテ乾 } \\
\text { チスル }\end{array}$ & $\begin{array}{l}\text { 八九月頃二地下荎习採掘シ } \\
\text { 水洗シ水中二石灰习混和 } \\
\text { シタル中ニ入レ煮沸シ日乾 } \\
\text { シ }\end{array}$ \\
\hline 1918 & 和漢薬物学 ${ }^{12)}$ & & & $\begin{array}{l}\text { 本品の蒸熱したる } \\
\text { ものを乾薑と云ふ } \\
\end{array}$ & \\
\hline
\end{tabular}


新鮮品と乾燥品の区別がないショウガ根茎を指し, 特に「乾 (乾燥)」や「枯（水が乾きひからびる状 態)」に加工寸る必要がある場合は「乾姜」,「枯姜」 と区別したと推察できる。

本草書では『神農本草経』(後漢) に初収載され, 辛温の薬能をもつ薬物とされたが，『名医別録』(後 漢）では性味が大熱と記載されだ)。大熱は附子に 代表される性味であり, 乾姜は非常に熱性が強い薬 物であることが窺われる。また, 『神農本草経』に は「生者尤良」とある。この記述は同書の乾地黄の

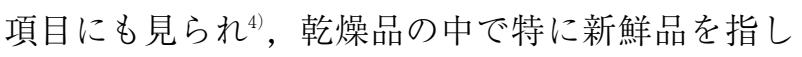
ていると考えられる。すなわち, 乾姜の中に新鮮な ショウガも包括していたと推察できる。なお, 同書 の乾姜の薬能に関する記述は新鮮品と乾燥品の 2 種 を指していると考察されている ${ }^{15)}$ 。一方，『神農本

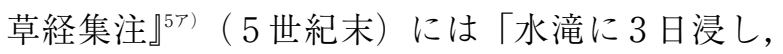
皮を去り, 流水中に 3 日扮き, 更に皮をむき, 日干 しする。その後陶磁器内で醸して得る。(水淹三日 畢 去皮置流水中六日 更去皮 然後晒干置瓮缸中 谓之醇也)」とあり, 乾姜の調製法が初見した。本 書には温と大熱の 2 種の性が記載されており, 上記 の調製法にて製した乾姜はいずれかの薬性をもつと 考えられる。宋代の『図経本草』（1062）には「漢 州乾姜法」と「温州白乾姜」の 2 種が記載された。 前者は『神農本草経集注』5)に記載の方法と同様で あるが，後者は「米のとぎ汁で煮る (一物漿水煮)」 とあり，地域により調製法が全く異なっている。な お, 漢州は四川成都府, 温州は浙江永嘉県に位置す る。

時代が下り，明代の『本草蒙鉒』（1565）には， 「去皮日曝, 又名乾姜」とあり, 乾生姜も乾姜の一 種として扱われ始めたことがわかる。また，『本草 崇原』引) (清初)には「乾畺用母畺晒乾」とあり, 乾美は乾生姜であると断定しており, 本書では性は 温としか記載されていない。清代初期には, 流水に 浸す調製法も記載されていたが, 清代の中期には『本 草従新』 ${ }^{5()}$ (1757), 『本草求真』 ${ }^{58)}$ (1769) などに

「薑曘乾為乾薑」とあり乾生姜の記載に代わった。 清代の本草書では, 薬性は『要薬分剂』』5) (1773) を除き, 温, 大温, 熱と記載され, 大熱の記載はな い。また, 『本草従新』占) (1757）では黒姜, 『医林 纂要探源』 ${ }^{5 \%)}$ (1758) では炮姜の性味が辛苦, 大熱 と示された。すなわち, 清代中期の乾姜は温性の乾
生姜であり, 修治により炮姜や黒姜とすることで大 熱の薬性に変化するとされた。一方, 斉代以後は地 域により調製法が異なっており，流水に浸して製す 乾姜は大熱の薬性を示したと考えられる。

良品に関する記載として, 李時珍は『本草綱目』8 （1596）中で「白淨結実者為良」と述へ，白くきれ いなものが良いとし，この記載が後世に伝承された。

（2）日本 (表 3 , 表 4 )

日本では, 『古事記』（712）に「垣もとに植えし 薑」とあり, 平安時代に既にショウガが栽培されて いたとされる 。また，『尺素往来』22)（1481）の薬 種の項目に「人参…桂心, 甘草, 川芦, 当帰などは 新たに渡来した済物であるが, 山薬, 牛膝, 牽牛子, …乾姜などは和薬であり, 御所にあるので献ずるに 及ばず (人参…桂心, 甘草, 川芎, 当帰…皆新渡之 済物候。山薬, 牛膝, 牽牛子, $\cdots$ 乾姜…等之和薬者。 御所持之間不及献之)」とあり，乾姜は中国からの 輸入品に依存せず, 古来, 日本独自に調製してきた ことが椝われる。

乾姜の調製法として, 曲直瀬道三著の『本草異名

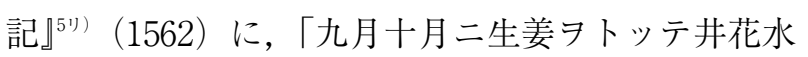
二浸スコト三日シテ皮タケヅリ去テ又流水二六日浸 ス。毎日水ヨカエテサテ日二乾シ焙リ用ユ」とあり, 漢州乾姜の調製法に類似するが, 陶磁器内で醸す過 程がない。本法は，『和名集并異名製剂記』57) (1623)， 『宣子製剤記』5゙（1579－1657）など曲直瀬道三の 門下による書物にも記載されている。また，『宣子 製剂記』场には，「本草可見取生者水二滝スコト三日 去皮置流水中六日更去皮晒干醸磁瓫中三日ニシテ紫 色ニシテ乃成蜀地ノ者佳」とあり, 漢州乾姜の調製 法も日本に取り入れられた。

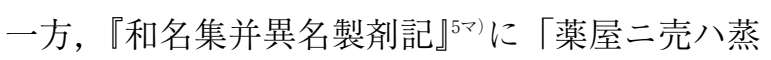
シ石灰ニマフシ置クナリ其八熱湯ニ浸シ上ノ皮卜石 灰卜タ削り去テ紙二包ミ水ニテヌラシ熱灰ニテ炮シ キサミ采テ使フ」とあり, 薬屋には蒸した後に石灰 をまぶして調製したものが売られていたようだ。ま た, 『農業全書』23)（1697）の薬種（乾畫）の項目に 「生姜のよく肥実したるを, 十一月のころざつと湯 煮して, 石灰に和し, よくほしあげ, 薬屋にうるべ し」, 亩 (はじかみ) の項目に「浄く洗ひざつと湯 煮して, かき灰にまぜ乾し上て篭などにもりをきて, 薬屋にうるべし」とあり，かき灰（かまどの灰）お よび石灰を乾燥剤として利用していたことが窺われ 
表 5 三河乾姜に関する記載内容

\begin{tabular}{|c|c|c|}
\hline 年代 & 文献名 & 記載内容 \\
\hline 1771 & 薬徵 ${ }^{57)}$ & $\begin{array}{l}\text { 本邦之産, 有二品。日乾生姜, 日三河漧羕。 } \\
\text { 所謂乾生姜者, 余家用之。所謂三河乾姜者, } \\
\text { 余家不用之 }\end{array}$ \\
\hline 1778 & 千金方薬註 ${ }^{57)}$ & 参河乾姜ハ石灰ヨ以テ製ス毒アリ \\
\hline $1729-1810$ & 本草綱目訳説 ${ }^{53)}$ & $\begin{array}{l}\text { 三河二テ製スルモノ良シ。今薬肆二三河乾姜 } \\
\text { 卜云モハハ真ノ三河二非ス偽物也 }\end{array}$ \\
\hline 1803 & 本草綱目啓蒙 ${ }^{9)}$ & 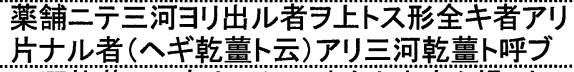 \\
\hline 1841 & 古方薬品考 ${ }^{20)}$ & 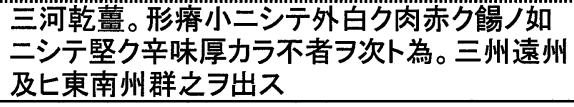 \\
\hline
\end{tabular}

る。しかし, 『用薬須知』 ${ }^{10)}(1726-1776)$ に「其色 ノ之白カラキヨ欲シテ石灰タ以テ䌂シ収メテ之ヨ売 ル毒有リ灰気ヨ洗去テ之用工可」とあり，石灰を用 いる理由は色を白く見せるためだとされる。これは， 『本草綱目』8 に白いものが良品であると李時珍が記 したことに起因しているものと思われる。

さらに，『炮采全書』5レ（1689）に「母薑五以テ略 ク煮過シテ然後之ヨ暴シテ乾サ令之タ乾葨卜名テ售 ル是二非」とあり，薬屋にはショウガを煮て調製し たものも乾姜として売られていたことがわかる。

明治時代になると，『和漢薬考』11)（1893）に「地 下茎ヨ蒸シテ乾干スル」とあり, 現代の日本薬局方 で規定されている方法が初めて記された。また，同 書に「地下茎丹採掘シ水洗シテ水中二石灰ヨ混和シ タル中ニ入レ煮沸シ日乾シ」ともあり，石灰を用い た調製も一部では行なわれていたと考えられる。一 方, 大正時代になり『和漢薬物学』に2) には本品の 蒸熱したるものを乾薑と云ふ」とあり，蒸製法のみ となった。

以上，江戸時代には，乾姜には大きくわけて，漢 州乾姜法，漢州乾姜法の醸す過程のないもの，蒸製 後に石灰をまぶす，煮て調製の 4 種の調製法があっ たが，明治時代には現在と同様の蒸製法が規定され， 大正時代にはそれに統一されたことが明らかになっ た。

（3）日本に扔ける「乾姜」と「干姜」の差異

江戸時代には「乾姜」と共に「干姜」の文字も存 在しており，それぞれ異なるものを指すことが明ら かになった。すなわち，「乾姜」は前述の 4 種の調 製法にて得られたものであるが，『食用簡便』5x

（1687）に「干姜［ホシシヤウガ］切片テ日ニ乾シ 用工」，『合類広益霊宝薬性能毒大成』9) (1715) に「乾 生姜卜ハ只干タル姜ナリ干姜ニ代テ用ユ」とあり,
「干姜」は乾燥ショウガすなわち乾生姜を意味する。 このことからも，中国での乾姜は乾生姜を指してい たと判断できる。さらに，『用薬須知』草に「乾生姜 八生姜ヨキザミソノママ日乾シテ收メ用ルナリ俗医 多ク此 ア以乾美卜為ル八誤ナリ」とあり，日本では 乾生姜を乾姜として用いるのは間違っていると述べ られ，両国での乾姜が異なるものと認識されていた ことが窅える。

（4）三河乾姜に関する記載内容（表 5 ）

江戸時代には「三河乾姜」と呼ばれるものが存在 し，『本草綱目訳説』录（1729－1810）に「三河ニテ 製スルモノ良シ」，『本草綱目啓蒙』19)（1803）に「薬 舗ニテ三河ヨリ出ル者ヲ上トス」とあり, 三河すな わち現在の愛知県の東部で製す乾姜は良品であると される。その性状は『古方薬品考』20) (1841）に「小 さく, 外面が白色で肉が赤く飴のように堅く, 味は 辛い（形㾑小ニシテ外白ク肉赤ク餳ノ如ニシテ堅ク

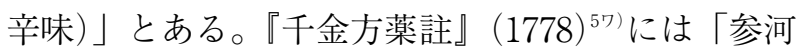
乾姜八石灰 いたとあるのは調査した中で本書のみであり, 確証 はない。一方，『本草綱目訳説』泉に「今薬肆二三河 乾姜卜云モノ八真ノ三河二非ス偽物也」とあり，三 河乾姜の偽物も出回っていたことがわかる。

\section{考察および結論}

1. 乾姜は本草書では『神農本草経』（後漢）に 初収載され，辛温の薬性をもつ薬物とされたが，『名 医別録』(後漢) では性が大熱と記載された4)。一方， 生姜は『名医別録』に初収載され，辛微温の薬物と された。すなわち，乾姜は生姜よりも温性が強い薬 物だと判るが，『神農本草経』の温と『名医別録』 の大熱では熱性が大きく異なり，別のものを示して いる可能性が考えられる。また, 『神農本草経』で は新鮮根茎も乾姜に包括していたと判断できる。乾 
生姜は温性, 梁代から調製法が明記された漢州乾姜 は大熱であることが明らかになったことから，『神 農本草経』では生姜と乾姜の区別がなく, 単に乾燥 した根茎または新鮮根茎を「乾姜」の名で収載し,

『名医別録』では新鮮根茥を生姜, 水に浸した後に 陶磁器内で醸した漢州乾姜を乾姜として収載したと 考えれば薬効の差も説明がつく。

2 . 馬王堆出土の前漢の医書および『神農本草 経』(後漢) では新鮮なショウガ根茥を乾燥品とは 区別してなく，『傷寒論』(後漢) では新鮮根茎を生 姜としていたことが明らかになった。また，前述の

『名医別録』は医家の張仲景や華佗の所記があると されるが24)，この書でも新鮮根茎を生姜としている と考察できた。すなわち，後漢代の医家が「生姜」

と「乾姜」を区別したと推察できる。

3. 中国では後漢末期以降，日本では少なくとも 江戸時代以降, 新鮮根茎を生姜としてきたことが明 らかになった。しかし，日本では明治時代に日本薬 局方に生姜を収載する際に, 乾燥根茎を採用し, 現 在に至っていると考察された。日本薬局方はオラン

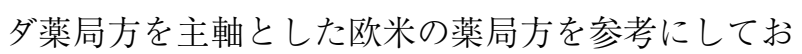
り, 漢方医学ではなく西洋医学を重視している。そ のため, 漢方医学のようにショウガの新鮮品と乾燥 品を区別する必要はなく, 保存に適した乾燥品を一 種の薬品として収載した可能性も考えられる。

4. 後漢から清代初期の本草書に扔ける乾姜の薬 性は,「温」と「大熱」の 2 種が存在したが，この 違いは修治法の違いによるものと考える。すなわち， 温は乾生姜, 大熱は水に浸した後に陶磁器内で醸し た漢州乾姜を指すと判断できる。しかし，『神農本 草経集注』 ${ }^{5 P)}$, 『本草蒙筌』などには修治法は 1 種 類しか書かれていない。これは，正しい修治を行な うと「大熱」の乾姜が得られるが, 実際には単に乾 燥させただけのものもあったため「温」も併記した と推測できる。

清代中期には「温」のみとなり, 乾姜は単に乾燥 させた根茎に統一されたと判断できる。それに伴い, 乾生姜を火熱して大熱性の炮姜, 黒姜に修治し, 漢 州乾姜に代わるものとしていたと考察できる。

5. 日本では, ショウガ根茎を乾燥させるために かき灰（かまどの灰）および石灰を利用していたと 考えられるが，『用薬須知』に视に白く見せるために 石灰を用いたとあり, 矛盾が生じる。これは, 乾姜
に石灰を用いた調製法が初めて『和名集并異名製剤

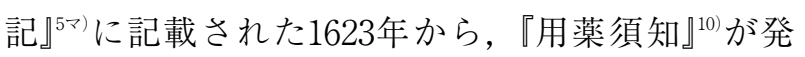
行された1726-1776年までの時代背景が影響してい る可能性がある。これに関連する事例として, 『本 草辨疑』5)（1681）に「洛下の薬舗遠藤元理は， $\cdots$ 遂に法製して, 人の求めに応ず，世に成薬店の始め とす」とあり, 本書発行前後で成薬店ができ, 医師 以外の人が生薬を修治するようになったことが挙げ られる。その後, 効能ではなく外見を重視した加工 を施し, 1700年頃には桔梗を煎茶で染め, 人参と称 して売りさばくなど, 薬舗では偽薬が多く販売され ていた ${ }^{25)}$ 。一方, 乾姜の良品については, 李時珍が

『本草綱目』で「白色の乾姜が良い」と述べたが, これは1637年に発行された日本初の『本草綱目』の 刊本 ${ }^{24)}$ で一般に広まったと考えられる。これを受け て, 薬舗では石灰で白くした乾姜を販売し, 本来乾 燥剂として使用してきたものの使用目的が変化した と考察できる。

6. 生薬の真偽について書いた『本草辨疑』らうで は乾姜には偽物がないととらえていたが,『本草綱

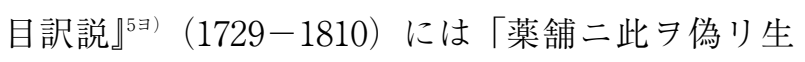
干ニ石灰ヨマブシ白メ售ル用二堪不」とあり, 石灰 をまぶしたものは偽物としている。このことから， 石灰を用いた乾姜の良否が变化したと推察できる。

7. 日本では, 平安時代には既にショウガが栽培 されており, 室町時代には乾姜も独自に調製してい たとされる。しかし, ショウガ根茎は乾燥し難いた め, 何らかの工夫が必要である。そこで, 経験的に かまどの灰を用いて乾燥させ，後に石灰を用いたと 考察できる。この石灰で乾燥させる方法は中国の本 草書には見られない。一方, スリランカの市場には 白い粉をまぶしたショウガ根茎が流通している ${ }^{26)}$ 。 このことから, 日本で石灰を用い始めたのは, 中国 医学ではなくインド伝統医学「アーユルヴェーダ」 の影響を受けた可能性も考えられる。

8. 江戸時代の乾姜の調製法には「蒸して石灰を まぶしたもの」の他に曲直瀬道三門下が伝授した「漢 州乾姜に類似するが醸す過程のないもの」,「漢州乾 姜法にて調製したもの」および「煮て調製したも の」が存在したことが明らかになった。この内, 漢 州乾姜法に類似したものは中国の影響を受けている が，日本古来の蒸製法は明治時代まで継続したと考 えられる。しかし, 江戸中期の偽薬問題で石灰が有 
毒だと判断され，石灰を用いなくなったと考察でき る。

9. 江戸時代には，中国の「乾姜」であるショウ ガの乾燥根茎を，日本では「干姜」の名で呼び，日 本の「乾姜」とは区別していたことから，両国にお ける「乾姜」は全く異なるものと認識されていたと 判断できる。

なお，中国では1964年に，「乾」は簡体字の「干」 に代わったが，日本では，1600年代に既に「干姜」 と呼ばれるものが存在していた。

10.『古方薬品考』20)（1841）には良品とされた三 河乾姜の性状として「小さく, 外面が白色で肉が赤 く飴のように堅い」とあるが，内部が飴のように堅 いのは，加熱処理によるデンプンの糊化によるもの と思われる。しかし，加熱処理を施すと外面も赤み を带びるため，白色であるのは別の調製を施してい ると考えられる。石灰を用いた可能性もあるが，こ れについての記述は今回調査した文献の中で 1 種の みであるため，確証はできない。このように三河乾 姜の調製法が不明確であるため薬舗では偽物も出 回っていたと考える。

11. 中国および日本では，「乾姜」と呼ばれるも のが数種存在し，特に大熱性の漢州乾姜と温性の乾 生姜では薬効が異なることが予想できる。今後，こ れらの薬効の違いについて化学的に検討する必要が あろう。

\section{引用文献および注釈}

1）第16改正日本薬局方, 厚生労働省 HP, http : //jpdb.nihs. go.jp/jp16/

2 ）国家薬典委員会編：中華人民共和国薬典2005年版一部, 化学工業出版社, 北京, 17-18, 2005

3 ) 劉渡舟, 姜元安, 生島忍: 現代語訳宋本傷寒論, 東洋 学術出版社, 千葉, 2000

4 ）唐慎微：経史証類大観本草（1108），木村康一編，東 京, 廣川書店, 205-206，1970

5 ）中国文化研究会編纂: 中国本草全書, 華夏出版社, 北 京, 1999 ; ア ) 陶弘景: 本草経集注 (500前後)， 5, 148-149， 亿）胡仕可: 本草歌括 (1295)，83，367, ウ）薛己：本草約言 $(1520), 26,214-216$, 工）皇甫 嵩: 本草発明（1578），56，447-449，才）梅得春：新 鐟薬性會元 (1595), 76, 481-482, 力）李中立: 本草 原始（1612），62，282-284， キ）盧之頣: 本草乗雅半 偈 (1647)，75，345，ク）張志聡注釈: 本草崇原（清 初)，95，429-430，ヶ)劉若金: 本草述 (1664)，91，2229，コ）郭佩蘭：本草匯 (1666)，86，161-163，サ） 閔鐡：本草詳節（1681），92，396-398， シ）程履新：
山居本草（1696），99，178-183， ス）黄元御：長沙薬 解 (1753)，102，460-464，七) 吴儀洛: 本草従新 (1757), 109, 197-199, ソ) 汪绂: 医林纂要 探源 (1758), 103, 400-401, 夕) 黄宮綉: 本草求真 (1769), 125，163-164，226-227，于）沈金鰲: 要薬 分剂（1773），105，408-409，ッ）羅國綱: 羅氏會約 医鏡 (1789)，109，465-466，テ）林玉友：本草輯要 (1790), 113, 338-339, 卜) 黄凱鈞: 薬籠小品 (1812)，118，123，ナ）王龍：本草纂要，119，6263，二）吴綱：類経證治(1827)，119，216，267, 又) 張徳裕: 本草正義 (1828), 117, 498, 535, 六) 張祫 録: 本草述録（1829），114，518-519，八）王世鍾： 本草 $(1837), 120,388-389$, 八) 凌奥: 本草害利 (1862)，144，378-379，383，419, 飞) 載荣元: 本 草綱目易知録（1885），142，199-202，フ）高硯五： 本草簡明圖説 (1887), 143，426， へ) 王象晋: 本草 撮要類編 (1897), 147, 416-417, 木) 周嚴: 本草思 辨録 (1904)，145，459-465， マ）梅寿: 和名集并異 名製剤記 (1623)，312，24，ミ）梅寿: 新添修治纂要 (1631)，312，119，公）撰者佚名：新編霊宝薬性能 毒 (1669)，312，488-489， メ）蘆川桂洲：食用簡便 (1687)，316，18，モ）撰者佚名:広益本草大成 (1701)，316，506-507，ヤ）加藤謙斎：增補片玉六 八本草 (1723)，320，436-437, 工）井上玄軾: 本草 製譜 (1723)，321，144-145，ヨ）小野蘭山：本草綱 目訳説 (1729-1810)，336，515，ラ）岡村尚謙: 本草 古義（1818-1829）, 341, 59-60, リ）曲直瀬道三: 本 草異名記 (1562), 355, 401, 几) 古林見宣: 増補宣 子製剤記（1579-1657），353，106，119，レ）稲生若 水: 炮多全書 (1689), 314, 515, 口) 平住専庵: 本 草售（1756），321，370-373，ワ）松岡典：千金方薬 註 (1778)，329，200， ヲ）吉益東洞：薬徵 (1771), 327, 503-506, ン）遠藤元理撰：本草辨疑（1681）, 313,470

6 ）王好古撰: 湯液本草（1248）, 人民衛生出版社, 北京, $161-163,1987$

7 ) 陳嘉謨 : 本草蒙鉒 (1565), 人民衛生出版社, 北京, 290292, 1988

8 ）李時珍: 本草綱目 (1596), 校点本, 人民衛生出版社, 北京，第二冊，849-852，1977

9 ) 三村玄碩：合類広益霊宝薬性能毒大成（1715）， 小ノ ミ漢方薬学叢書, 巻15, 生姜, 119-120, 1987

10）松岡玄達: 用薬須知 (1726), 難波恒雄編集, 漢方文 献刊行会, 大阪, 54-56, 1972

11）小泉栄次郎: 和漢薬考 (1893), 大耀社, 東京, 418429, 1972

12）日野五七郎, 一色直太郎: 和漢薬物学 (1918), 木ノ 漢方薬学叢書, 卷15，生姜，175，1987

13）改正日本薬局方（1891）, 図書出版, 国立国会図書館 近代デジタルライブラリー, http : //kindai.ndl.go.jp/

14）馬継興: 馬王堆古医書考釈, 湖南科学技術出版社, 湖 南, 1992

15）玄振玉，劉明嶺：干姜，生姜薬用源流考辨，上海中医 薬雑誌，37(2)，48-50，2003 
16) 下津元知：図解本草 (1680), 難波恒雄編集, 大阪漢 方医学研究所, 大阪, 64-65, 1981

17）香川修庵：一本堂薬選（1729）, 難波恒雄編集, 漢方 文献刊行会，大阪，71-73，1976

18）香月牛山：薬籠本草 (1734), 難波恒雄編集, 漢方文 献刊行会，大阪，401-408，1974

19）小野蘭山：本草綱目啓蒙（1803）, 杉本つとむ編著, 早稲田大学出版部，東京，348-349，1974

20）内藤蕉園：古方薬品考 (1841), 燎原, 東京, 37-40, 1974

21）青葉高：野菜の日本史，八坂書房，東京，2000
22）一条兼良撰と伝えられる：尺素往来 (1440-1464), 塙 保已編纂, 群書類従, 続群書類従完成会, 東京, 9 , 512, 1960

23）宮崎安貞：農業全書（1697）, 山田龍雄編, 日本農書 全集，農山漁村文化協会，東京，12，291-295，13， 289, 1978

24）岡西為人：本草概説，創元社，大阪， 1977

25）吉岡信：江戸の生薬屋，青蛙房，東京，1994

26）筆者の御影らが2004年にスリランカに調査に行った時 に確認した 